\title{
Practice Before California Licensing Agencies
}

\author{
John G. Clarkson*
}

California probably has created as extensive and diversified a group of administrative agencies exercising adjudicative powers as any state. ${ }^{1}$ They have been created in several ways. ${ }^{2}$ Some of the executive agencies are established essentially to perform specific governmental functions. ${ }^{3}$ Perhaps most executive agencies in California exercise some part of the sovereign police power including regulation of activities which nay affect public health, safety or general welfare. Among these are agencies concerned with the relationships of business or professional nature between persons.

In 1945 the California Legislature enacted a program to channel the exercise of some powers of specified regulatory agencies involving rights, authority, hicense or privilege. 4 The act was limited to apply to the "more common licensing" of businesses, professions and occupations ${ }^{5}$ and sought to impose basic concepts of due process or fair hearing in the disciplinary programs of the desiguated agencies. ${ }^{6}$

* Chief, Division of Administrative Procedure, Department of Professional and Vocational Standards, State of California; Member, State Bar of California.

\footnotetext{
1 Councri of State Governarents, Occupation Licensing Legislation in the States, Appendix B (1952). California has since added several more occupations. See annotations to the California Administrative Procedure Act pamphlet prepared and distributed by the Division of Administrative Procedure.

2 Adjudicative powers have been created by grant of plenary powers in the constitution, e.g., Industrial Accident Commission and Public Utilities Commission, see 2 Cax. JWR. 2d, Administrative Law $\$ 12$ (1952); by enabling provision in the constitution, e.g., State Personnel Board, Board of Health, Alcoholic Beverage Control, vice Board of Equalization, see 2 Cat. JUR. 2d, Administrative Law $\$ 12$ (1952); by initiative legislation or referendum, e.g., Osteopathic Act (Deering's General Laws No. 5727), Chiropractic Act (Deering's General Laws No. 4811), see 2 CAx. Jur. 2d, Administrative Law $\$ 13$ (1952); but mostly by legislative action. The source of the creation has contributed to problems in this field as to kind and extent of powers and the nature and scope of judicial review, in part as a result of judicial declarations. See Kleps, Certiorarified Mandanuls, 2 Stan. L. Rev. 285 (1950).

3 E.g., Department of Finance, Department of Veterans' Affairs.

4 California Administrative Procedure Act, CaI. Govr. Code $\$ \S 11500-11528$, especially $\S \S 11503,11504,11517$. Not all licensing in California is subject to the act. TENTH BIENNIAL Report, Judiciat Counctr of Cartfornta 9-10, 16 (1944); 2 Cat. Jur. 2d, Administive Law $\$ 61$ et seq. (1952).

5 Tenti Brennial Report, Judictal Councre of Cartfornta 9, 13 (1944). This report implies that the basic principles of the act may later be extended to other kinds of administrative action. It also explains why the act did not at the time of its enactment apply to all licensing functions. Relative to the issuance of permits by the Corporations Commissioner, see Car. CORP. CODE $\$ 25500$ et seq.

8 The legislative program also created a Division of Administrative Procedure. See Cad. Bus. \& Prof. Code $\$ \$ 110.5,110.6$, and Cat. Govt. Code \$ 11502. Tentr Biennaal Report, Judictal Councic of Califormia 31 (1944).
} 
In 1947 the Administrative Procedure Act was extended to require publicity and to prescribe procedural regularity in the exercise of delegated quasi-legislative power by nearly all executive or administrative agencies.

Licensing in a broad sense includes the determination by an authority of whether one who seeks a right, authority, license or privilege ${ }^{8}$ has met the legislative standards so as to be entitled to receive the right. This activity includes an exercise of legislative power to implement or set standards, prepare application forms and the examinations or tests, accept applications and appropriate fees, and maintain examination facilities and records of licensees and renewals. ${ }^{\circ}$ There are several legislative patterns in California. The greater the public interest, the broader may be the discretion delegated to the regulatory authority. The less inimical to public welfare or morals, the more specific the standards set out in the legislation. The licensing authority is to apply the standards and determine whether to issue the license. The law may require certain educational prerequisites, experience, knowledge to be established by test or examination, financial responsibility, or integrity of character. ${ }^{10}$ Some statutes require that any definitive determination other than on an objective test be made only after proceeding pursuant to the Administrative Procedure Act. Other statutes do not specifically do so. ${ }^{11}$ However, the courts upon occasions have expressed the view that wherever there is to be a determination of fact on which discretion is to be exercised, a hearing may be required.

In consideration of a license application, when the administrator determines that objective standards or tests are not enough to establish a basis

7 CAL. Govt. CoDE $\$ \S 11370-445$. Section 11445 specifically exempts the Public Utility Commission and the Industrial Accident Commission from provisions of the Administrative Procedure program. The regulations whose publication is required are published in the California Administrative Code and Register. See also First BIENNIAr Report, Division of AdMINISTRATIVE ProCEDURE 13-17 (1947).

${ }^{8}$ The statutory definition is comprehensive. Hereafter the single word "license" may be considered to refer broadly to all that may be included in the plirase.

${ }^{9}$ This is sometimes made more clear by statute, e.g., relative to contractors see Cax. Bus. \& Prof. Code $\$ \S 7059,7065$. Relative to real estate licenses see CAL. Bus. \& Prof. Code $\$ \$ 10153$, 10154. See also id. $\S \S 5018,5033$ (accountants); id. $\S 6545$ (barbers); id. $\$ \S 6750,6754$ (civil engineers); id. $\$ \$ 6888,6889$ (collection agencies); id. §7622 (funeral directors); id. §3052 (optometry); id. $\$ 2280 \mathrm{et} \mathrm{seq.} \mathrm{(doctors).} \mathrm{As} \mathrm{to} \mathrm{procedure} \mathrm{relative} \mathrm{to} \mathrm{regulations} \mathrm{generally,}$ see CAL. Govt. Code $\$ \$ 11370-445$, Chapter 4, A.P.A., and also 2 CAr. JUr. 2d, Admintistrative Laze § 76 (1952).

10 Graduation from approved schools: e.g., barber, Car. Bus. \& ProF. Code $\$ 6535$; dental, id. $\S 1628$, Ex parte Whitley, 144 Cal. 167, 77 Pac. 879 (1904), funeral director, CaL. Bus. \& PROF. CODE $\$ 7622$; plyysician and surgeon, $i d$. . $\$ 2171-2174$. Character or reputation: contractors, id. $\S \S 7069,7073$; dentists, id, $\S 1628$; real estate, id. $\S 10150$. Generally see 2 CAL. Jur. 2d, Admintistrative Law, 112 n.15 (1952).

11 See, e.g., CAL. Bus. \& Prof. CoDE $\$ \$ 6906,6923,6926$ (collection agencies); id. $\$ 1670$ (dentists) ; id. §3090 (optometry); id. § 2360 (doctors); id. §5102 (accountants); id. \$§ 7073, 7091 (contractors); id. § 10100 (real estate); id. §24016 (liquor licenses). 
upon which he can properly act, he may be required to set the matter for formal hearing under the Administrative Procedure Act or some proceeding like unto it. ${ }^{12}$ Under that act such proceeding is imstituted by the preparation of a Statement of Issues.

There are statutes which contemplate intervention by others than the regulatory agency..$^{13}$ The Administrative Procedure Act envisions imitiation of a Statement of Issues by another, although it is the regulatory agency before which the application is pending that prepares this document in most cases. ${ }^{14}$ Here is an area in which the responsibility of the agency warrants extensive inquiry into any relevant facts. It is argued that the license carries an implication to the public of state approval of the licensee as to character and competence as well as authorization to engage in the licensed activity.

In such proceedings the burden of proof to establish the right to receive the license sought remains with the applicant at all stages. ${ }^{15}$ However, the practice has evolved whereby the agency before which the application is pending will present for the record that which has come to its attention which led to the determination that the matter should be set for formal hearing. The statute requires such to be set forth in the Statement of Issues. In other respects such proceeding generally follows the same pattern of an adversary proceeding under an accusation to be discussed hereafter.

Incident to a grant of administrative power to regulatory bodies are investigative or inquisitorial powers. ${ }^{16}$ Upon completing the investigation the staff will submit a summary or report to an authorized staff member for determination of the appropriate action to be taken. There may be a statutory basis for any one of several administrative acts. For instance, the agency may refer the case to a prosecutor for instituting criminal action. ${ }^{17}$

12 Andrews v. State Bd. of Registration, 123 Cal. App.2d 685, 267 P.2d 352 (1954); see also Weiss v. State Bd. of Equalization, 40 Cal.2d 772, 256 P.2d 1 (1953); West Los Angeles Citizens etc. v. State Bd. of Equalization, 111 Cal. App.2d 843, 245 P.2d 571 (1952) ; Altadena Commumity Church v. State Bd. of Equalization, 109 Cal. App.2d 99, 240 P.2d 322 (1952).

13 See, e.g., Cax. Bus. \& Prof. Code $\S \$ 7090,23988,24013$.

14 CAx. Govr. CODE $\$ 11504$. Quaere: May an applicant prepare it and file with the agency or is an applicant's remedy in an extraordinary writ where action is dilatory on an application? Note, too, informality of pleading and notice of hearing. Id. $\$ 11504$.

15 McDonough v. Goodcell, 13 Cal.2d 741, 744, 91 P.2d 1035, 1037 (1939) (the leading case). See also Southern Calif. Jockey Club, Inc. v. California Horse Racing Bd., $36 \mathrm{Cal} .2 \mathrm{~d}$ 167, 223 P.2d 1 (1950).

16 Car. Bus. \& Prof. Code $\S \S 108,108.5,153$; Car. Govt. Code $\$ \$ 11180$ et seq., 18670. See also 2 CaI. JUR. 2d, Administrative Law $\$ 34$ (1952). It is argued by some that the licensee, having secured the privilege or status which carries a semblance of approval by the state of his character and competence, is under a correlative duty to co-operate with investigation, visitation and inquiry by the regulatory authority. See, e.g., CAx. INs. CoDE $\$ \S 1663,12903$, and $\S \S 1042$, 12924 relative to subpoenas. See also Car. BUs. \& Prof. CODE $\$ \S 5525,5526$ (architectural examiners) ; $i d . \$ \S 7625,7626.5$ (funeral directors); $i d . \$ 4380$ (pharmacy); $i d . \$ \S 18627$, 18714 (athletic commission).

17 Most frequent reference for prosecution occurs when the agency discovers nonlicensed persons engaged in the activity proscribed to all but properly licensed persons. See CaI. BUs. 
Where the statutory power exists, ${ }^{18}$ civil proceedings may be instituted to restrain or enjoin the persons subject to the jurisdiction of the particular agency from further violations of the act. Informal adjudications and determinations are not unknown. ${ }^{19}$ Finally, formal disciplinary proceedings may be started. As to those agencies and relating to the functions subject to the act, such proceeding is instituted by the filing of an Accusation under the Administrative Procedure Act. ${ }^{20}$

Upon filing the Statement of Issues or Accusation, if not before, the matter becomes a contested case within the contemplation of this statutory program. ${ }^{21}$ Commencement of the action and the ultimate decision must be based upon some statute, regulation, decision, or other foundation in law. This point should never be overlooked.

In proceedings on an Accusation the burden of establishing a basis for adverse disciplinary action rests upon the agency or other moving party who files or causes the Accusation to be filed.

The California act requires the service upon affected parties ${ }^{22}$ of a Statement of Issues ${ }^{23}$ or of the Accusation. ${ }^{24}$ Service of the Accusation or Statement of Issues nay be personal or by registered or certified mail, but such service by registered mail is effective only if a statute or agency rule requires respondent to file his address with the agency and notify the agency of any change. While this has the significance and effect of a complaint in a civil or criminal action, in administrative law its primary function in addition to instituting the adversary proceeding is to constitute notice to the respondent of what he may be expected to encounter at the hearing. Each will, in effect, assert jurisdiction and power of the agency

\& Prof. CoDe $\$ 7030$. By some statutes one is denied recovery in civil litigation if acting in the regulated activity without proper license. Id. $\$ 7031$. See Oddo v. Hedde, $101 \mathrm{Cal}$. App.2d 375, 225 P.2d 929 (1950).

18 See, e.g., CaL. Bus. \& Pror. CoDE $\$ 5117$ (accountants); id. $\$ 9533.6$ (dry cleaners); id. $\S 1705$ (dentistry); id. $\$ 2436$ (medicine). See also Cal. CoRp. Code $\S 803$ and CaL. Fin. CoDe § 12307.1 (check sellers and cashers); CAL. Buss. \& Prof. Code § 1008 (real estate).

10 This is a fertile field for counsel to effectively represent a client. The nature of the activity and the agency involved will imdicate the degree to which informality may be effective. See Tenth Biennial Report, Judicial CouncII of California passim (1944). See, e.g., Cas. Bus. \& Prof. Code $\$ 7687.5$ (funeral directors). See also Davis, Administrative Law 137 (1951).

20 CaL. Govt. CODE $\$ 11503$. Some agencies have summary powers to act where the lealth, safety, or general welfare of the public is directly affected. See CaL. Venucle Code $\$ 302$ et seq.; Cal. Bus. \& Prof. Code $\$ 2385$ (medical board) ; Cal. Health \& Safety Code $\$ \S 2523,2558$, and CaL. Educ. CoDe $\$ 13526.1$.

21 CaL. Govt. Code $\$ \S 11503,11504,11517$ (a).

22 The party against whom the accusation is filed is called Respondent. Id. $\$ 11500(\mathrm{c})$. Quaere: whether a protestant under the Business and Professions Code is a "party"?

23 CAL. Govt. CODE $\$ 11504$.

24 Id. $\$ 11503$. See note 27 infra. 
to act. ${ }^{25}$ Technicalities of pleading are avoided by reason of the requirement that the paper merely be "a written statenrent of charges which shall set forth in ordinary and concise language the acts or omissions with which the respondent is charged, to the end that the respondent will be able to prepare his defense." ${ }^{26}$

With the initiatory pleading there shall be served ${ }^{27}$ upon the respondent a statement to respondent and a post card or form of notice of defense. ${ }^{28}$ Substantially, this statement tells respondent that he may respond to the Accusation on the accompanying notice of defense, how to do so, and the consequence if he does not do so within fifteen days. Unless specific matters such as objections, admissions, or affirmative defenses are set forth, the mere filing of a notice of defense constitutes a general denial and puts in issue all relevant matters alleged in the initiatory pleading. ${ }^{29}$

In addition to the provision for admissions in the responsive pleading, the act provides that an omission to file within the prescribed time will authorize the agency to take action. ${ }^{30}$ Such failure to file promptly apparently does not constitute an admission of all facts pleaded, as the section authorizes action in such event "based upon the respondent's express admissions or upon other evidence and affidavits may be used as evidence without any notice to respondent." ${ }^{131}$

Informality characterizes the entire proceedings. Some qualification should be made of such a broad statement. Order is heaven's first law. Where these hearings are presided over by a trained and experienced lawyer or, for that nuatter, anyone who has a sense of logic and chronology, informality does not mean chaos. It may, therefore, be generally stated that experienced members of the bar approaching a formal adversary hearing before a California administrative agency need not anticipate a situation

25 This is accomplished by recital of respondent's license status and by reference to a statutory basis for the proposed action contemplated by the pleading, e.g., CAL. Bus. \& Pror. Cone $\S \S 7091$ and 7106.5 (contractors); id. $\$ 10302$ (real estate). Cf. Stuck v. Board of Medical Examiners, 94 Cal. App.2d 751, 211 P.2d 389 (1949).

20 Cat. Govt. Code $\$ 11503$. This language is similar to that set forth in Car. Code Crv. Proc. § 426. Observe Davis, Adminnistrative Law 278 (1951): "The most important characteristic of pleadings in the administrative process is their unimportance. And experience shows that unimportance of pleadings is a virtue."

${ }^{2 \tau}$ CAL. Govt. Code $\$ 11504$, concerning the Statement of Issues, describes service. Id. $\$ 11505$ describes the manner of service of an Accusation and the documents to be served with it.

28 Id. $\$ \$ 11503,11504,11505$. The latter specifies the manner of service.

29 Id. $\$ 11506$.

30 Id. $\$ 11520$.

31 Ibid. Here, as in contested cases, when no request is made for examination of affiants, the sworn facts constitute direct evidence. See Appeal of Palomino, Alco. Bev. Control Appeals Board No. 158 (1955). See also Drv. Anarin. Proc. Bulx. No. 11 (1955). Quaere: May "other evidence" be only that admissible in contested matters as required in CAL. Govr. Cone $\S 11513(c)$ ? 
in which they will feel at all uncomfortable or in which they need abandon those basic precepts that should regulate orderly conduct of any contested formal hearing. Procedural fairness and the accumulated experience of generations urge conformity to such conduct. Thoroughness and care in preparation and presentation will bring their appropriate rewards in administrative as well as other contested matters.

There are certain provisions of the California Administrative Procedure Act that bear upon this matter of adequate preparation. Reference has been made to the section providing for special defenses. ${ }^{32}$ The act contemplates administrative action in a less formal way in the event the named respondent in the initiatory pleading sees fit either not to respond by a notice of defense or not to appear later at the hearing in the event a notice of defense was filed. ${ }^{33}$ In civil and criminal proceedings pleas of guilty, consent to judgment, compromise, or adjustment may occur.

Although the act does not specifically provide for it, the possibility of prehearing conferences should be considered. If the agency is open to such a meeting, beneficial results attributed to this device in civil actions might ensue. Reference has been made to the investigatory powers exercised by these agencies ${ }^{34}$ and to informal methods of adjudication ${ }^{25}$ prior to filing formal charges. Many agencies are receptive or may even initiate opportunities durmg the investigation and the development of evidence for the parties who may be affected by possible adversary action to meet with staff members. This contact may lead to an understanding by way of explaining the facts disclosed by the investigation that might otherwise be the basis for adversary disciplinary action within the statutory program of the particular agency. If such opportunity is not made available, it would not appear improper or unwise for affected persons and/or counsel to seek the opportunity to discuss the matter with the appropriate staff member of the regulatory agency. Whether or not this may upon occasion avert formal action, it would certainly facilitate the development of relevant evidence upon behalf of the agency or the contemplated respondent. The opportunity may be available to mitigate the offense or the sanction. ${ }^{36}$

The suggested informal approach may be even more significant in connection with proceedings that may follow an inquiry relating to the qualifications of one seeking a license. The agency may merely require informa-

32 CAL. Govt. CODE $\$ 11506$. See note 29 supra.

33 CAL. Govr. CoDE $\$ 11520$ authorizes the agency to take action without a hearing. The section contains some restrictions, however.

${ }^{34}$ See note 16 supra.

35 See note 19 supra.

${ }^{36}$ See CaL. Bus. \& Prof. Code $\$ 7095$; Terminix Co. v. Contractors' State etc. Bd., 84 Cal. App.2d 167, 190 P.2d 24 (1948). Cf. CAL. Bus. \& Prof. CoDE \& 7102; id. \& 2376.5 (medical); Cax. Govt. Code $\$ 11522$. 
tion required by law or by the regulations of the agency. The application forms or instructions may not be clear, or certain items may have been overlooked by the applicant.

Ordinarily it is too late to approach an agency after a matter in an Accusation is at issue. One might then consider a request to the assigned hearing officer ${ }^{37}$ for a prehearing conference. He may arrange suclı conference to consider simplification of the issues, stipulations, or agreements, or to make witnesses or documents available. ${ }^{38}$

In further consideration of the formal provisions of the Administrative Procedure Act which will facilitate the development of pertinent facts at the formal hearing, attention is directed to the sections relating to subpoenas, ${ }^{39}$ depositions in appropriate cases, ${ }^{40}$ and the use of affidavits. ${ }^{41}$ Another matter that often precedes the actual hearing on the merits is that of a continuance. ${ }^{42}$ The limited staff to serve a large number of agencies in a vast geographical area, together with limited budgetary provisions, precipitated an amendment in 1953 designed to give the Division and its staff some control over frivolously sought or readily granted postponements, once a proposed hearing was at issue and ready to be heard. It may now be anticipated that a continuance will not lightly be granted. Generally, if a legal basis is established and if its denial under the circumstances presented might be construed by a reviewing court to be a denial of due process or an arbitrary act, the continuance will be granted. Otherwise it will not. ${ }^{43}$

One may anticipate little difficulty in determining the time and place for these hearings. The hearing is normally scheduled to be heard at the place where the transaction occurred or at a place convemient to respondent. ${ }^{44}$ There are circumstances when the convenience of witnesses and of the parties together with the expense might dictate setting the matter to be heard elsewhere. To a respondent who has filed a notice of defense, a notice

37 See Cat. Govt. Code $\$ \S 11502,11524$, and Cat. Bus. \& Prof. Code $\$ 110.5$.

${ }^{38}$ Cf. Dyment v. Board of Medical Examiners, 57 Cal. App. 260, 207 Pac. 409 (1922).

39 CAL. Govr. CODE $\$ 11510$. If a subpoena is desired prior to the hearing the agency will issue it upon request. If one is required after the hearing has started the hearing officer will issue it. However, an affidavit showing materiahty is a condition precedent to a subpoena duces tecum being issued, and a copy of the affidavit must be served with a copy of the subpoena.

Cat. Code Crv. Proc. $§ 1987.5$.

40 CAL. Govt. CODE $\$ 11511$.

41 Id. $\$ 11514$.

42 Id. $\$ 11524$.

43 Nahas v. Nahhas, 135 Cal. App.2d 440, 442, 287 P.2d 381, 382 (1955): "The mere absence of a party standing alone is insufficient to compel the court to grant a continuance."

44 CAL. Govr. CODE $\$ 11508$; McPheeters v. Board of Medical Examiners, S2 Cal. App.2d 709, 187 P.2d 116 (1947). See also Duval v. Contractors State License Board, 125 Cal. App.2d 532, 271 P.2d 194 (1954), and Drv. Admm. Proc. Buxls. No. 1 (1948), No. 8 (1953) and Nos. 6, 7 and 8 (1954). 
of hearing ${ }^{45}$ will disclose the time and place and again remind him of his rights in the proceeding, such as the right to representation by counsel, confrontation and cross-examination of witnesses, issuance of subpoenas, and presentation of relevant evidence.

The time is set and we have met. The hearing will be called and the record opened. The agency for whom the proceeding is to be held will have determined whether it is to hear the case with the hearing officer presiding or whether the matter shall be heard by a hearing officer alone. ${ }^{40}$

At this point the question of challenges relating to disqualification becomes pertinent. Any such challenge must be made by filing an affidavit "prior to the taking of evidence at a hearing, stating with particularity the grounds upon which it is claimed that a fair and impartial hearing can not be accorded." 47

When the hearing officer sits with the agency he will preside and conduct the hearing. ${ }^{48}$ Obviously, during the course of the matter the agency or members thereof will be afforded an opportunity to inquire into relevant evidence from the witnesses and to examine documents. It must be remembered that although the hearing officer is presiding, the ultimate deciding authority is the "agency," which must find the facts, determine the issue, and establish the sanction. Deliberation in executive session will ordinarily follow the hearing. The hearing officer must be present at the executive session and advise and assist the agency in the entire process. ${ }^{40}$ The agency may or may not announce its decision after the executive session. In any event, its written decision will thereafter be served on the parties and counsel of record.

When the hearing officer is to sit alone, "he shall exercise all powers relating to the conduct of the hearing." ${ }^{50}$ Reference will be made to his other duties later.

The so-called pleadings--initiating and responsive documents-will be identified and made a part of the record. This is necessary in these proceedings because there is no file in the sense that the pleadings and moving papers have been filed as part of the record of the particular matter. ${ }^{51}$ The hearing officer will frequently comment that the pleadings will be thus identified and/or made a part of the record but without evidentiary effect

45 CAL. Govt. CODE $\$ 11509$.

$46 I d . \$ 11512$ (a). The assignment at the request of the agency of a hearing officer of the Division of Administrative Procedure will be referred to and incorporated in the record.

${ }_{4 \pi} I d . \$ 11512(\mathrm{c})$.

$48 I d . \$ 11512(\mathrm{~b})$.

49 Id. $\$ 11517$ (a).

50 Id. $\$ 11512(\mathrm{~b})$.

51 E.g., enclosed in a file cover by a clerk as constituting part of the record in the case in a court of record. 
except as to the jurisdictional recital and any affidavits or other evidence of service of the significant papers.

Upon occasion counsel may be afforded an opportunity to make a brief statement as to the scope of the issues believed to be involved. This is often done at the instance of the hearing officer or of counsel for the agency where the agency itself is hearing the case, particularly where it consists of a multiple-headed agency. In the event the agency had theretofore read the pleadings this is a refresher; otherwise, it initially informs those present of the basic issues and charges made.

Perhaps other matters should be mentioned here, as they often occur at this point, before the first witness is called and sworn. In addition to prehearing conferences and the provision for filing special defenses, ${ }^{52}$ various motions, such as motions in the nature of demurrers, may be raised. Although the Admimistrative Procedure Act does not prohibit these motions, they are normally of little value. Assuming the Accusation is informative regarding an issue within the jurisdiction of the agency, the Administrative Procedure Act provides for amended or supplemental accusations. ${ }^{53}$ The rules in civil proceedings permitting amendment to conform to proof ${ }^{54}$ and the laudable desire that controverted matters may be determined upon the merits rather than by technical maneuvers of a legalistic nature impel the conclusion that technicalities and dilatory tactics are to be discouraged. The act affords protection to a party affected by such amendment and the rights of the respondent are always guarded by the hearing officer. In the event the amendment is made or a supplemental accusation is filed, the respondent must be given a reasonable opportunity to prepare his defense, but he need not, in fact may not without agency approval, file a further pleading. All new charges are deemed controverted and any objections to the amended or supplemental accusation may be made orally and are incorporated in the record.

The agency has full control of amendnients to pleadings and supplemental pleadings at all times. The hearing officer has no control over the agency's acts in this respect. His only function is to determine appropriate procedure after the amendment has been made. The suggested amendment will seldoni change the nature of the cause alleged. If it does, the respondent is entitled to a continuance to meet the new cause stated. What may have appeared to be prejudicial when the amendment was first made may prove to be entirely harmless in view of the nature and character of the proof or the stipulations of the parties. Experience has shown that amendments are

\footnotetext{
52 CAL. Govt. CoDE $§ 11506$.

53 Id. 11507.

54 Cax. Code Crv. Proc. $\$ 469$ et seq. See also Cax. Govt. Code $\S 11516$ relative to amendments after submission for decision.
} 
not numerous and when made do not interfere with an orderly disposal of the proceedings.

The tendency is to permit the hearing and its immediately prior phases to consist of a broad search for relevant facts, even to an extent which might, upon occasion, appear to be "fishing." The entire scheme is designed to facilitate the search for the ultimate truth with respect to such relevant facts. In carrying out the broad disciplinary program, the general public interest must not be forgotten. This is particularly true in hearings on Statements of Issues. There appears to be no valid reason to preclude an agency from making a full inquiry into all relevant matters within the scope of a statute designed by the legislature in the interest of public health, safety or general welfare, ${ }^{55}$ before the agency grants a license.

The representative of the moving party will now begin the presentation of evidence by calling witnesses and/or by introducing documentary evidence.

What is thought by many to be the very heart of this act, and perhaps of all adversary administrative action, is the provisions relating to the rules of evidence. ${ }^{56}$ The act provides that the hearing need not be conducted according to technical rules of evidence and that any relevant evidence shall be admitted if it is the sort of evidence upon which responsible persons are accustomed to rely in the conduct of serious affairs, regardless of the existence of any common law or statutory rule which might make improper the admission of such evidence over objections in civil actions.

Hearsay evidence is admissible for the purpose of explaining or supplementing direct evidence, but it will not take the place of direct evidence in supporting a finding of fact. ${ }^{57}$ Although the ultimate burden of proof does not shift, there is considerable latitude in the discretion of the presiding officer in directing or permitting changes in the order of proof.

One item that has given some concern in these proceedings is the last sentence of subdivision (b) of Government Code section 11513. It reads: "If respondent does not testify in his own behalf lie may be called and examined as if under cross-examination." As interpreted by the California

\footnotetext{
55 See note 16 supra.

56 See Car. Govr. Code $\$ 11513$ especially, but also the sections relating to the means of production thereof, as e.g., subpoenas, depositions and affidavits. Occasionally the regulatory statute may indicate the manner of proof, e.g., CAL. Bus. \& Prof. CoDE $\$ \S 2383$, 2377. Under the former section the record of a conviction constitutes proof of a basis for discipline. Under the latter section proof of facts constituting a disciplinary offense would be the directive. See Davis v. State Bd. of Medical Examiners, 108 Cal. App.2d 346, 239 P.2d 78 (1951), and Drv. Admrn. Proc. Butrs. Nos. 1 and 2 (1952).

57 See Manning v. Watson, 108 Cal. App.2d 705, 239 P.2d 688 (1952), and Drv. Apmns. Proc. Bulus. Nos. 2 and 3 (1952). Cf. Karrell v. Watson, 116 Cal. App.2d 769, 254 P.2d 651 (1953), and Drv. Admrn. Proc. Bulus. Nos. 4 and 5 (1953).
} 
Attorney General, ${ }^{58}$ the "if" implies a direction of the order of proof to the extent that the agency is to be required to present in good faith all of the relevant evidence available to it in support of the allegations in the accusation before seeking to call respondent to testify as on cross-examination. It will be observed that this provision is a modification of the well known Code of Civil Procedure section 2055. It has also been observed that it may be a reasonable modification of the rule in criminal proceedings that a defendant may not be required to testify against himself. ${ }^{59}$ The interest involved being one of license rather than right, the act does not contemplate that the agency may not have the benefit of the testimony of respondent if necessary to fully present its case in support of charges set forth in an accusation. The provision is consistent with the basic intention that the accusation shall serve as notice to the respondent of that which he is to meet. The agency should present all other relevant evidence before seeking to complete its proof through the mouth of respondent. In a sense, it calls for a prima facie showing, but by no means requires the agency to prove all the elements of the offenses alleged by a sufficient preponderance of evidence to support an order without respondent's testimony. This would make the words of the act meaningless. ${ }^{60}$

In all other respects any witness may be examined on any relevant evidence, regardless of who may have called him. The rules of privilege and of confidential records are respected.

The California act ${ }^{61}$ provides a somewhat more liberal provision for official notice than is available generally in civil proceedings. The very nature and justification for administrative tribunals suggest the basis and reason for this extension of the usual rule authorizing judicial notice ${ }^{62}$ which is incorporated by reference and extended to include generally accepted technical or scientific matter within the agency's special field. There is a protective provision, however, which requires that the parties present shall not only be informed of the matters noticed but that they shall be noted in the record, referred to therein, or appended thereto, with a reasonable opportunity to any party to refute the officially noticed matters by evidence or written or oral presentation of authority upon request. ${ }^{63}$

5811 Ops. Cax. AtT'y. Gen. 116 (1948).

59 Tenter Bienaial, Report, Judiclat Councer of California 21-22 (1944). See also Cat. Ins. Code $\$ \S 764,784$; CaL. Bus. \& Prof. Code $\$ 16758$, CaI. Corp. Code $\$ 25354$.

60 For further discussion of this general problem see Note, Administrative Law: Agency Calling Party as Witness at Hearing: Government Code Section 11513(b), which appears in this issue infra.

61 Car. Govt. Code $\$ 11515$.

02 Cat. Code Civ. Proc. § 1875.

63 In re Engelberg, Alco. Bev. Control Bd. Appeals No. 199 (1956). The hearing officer included findings of fact in a proposed decision based upon official notice. The record failed to comply with the provisions of Government Code section 11515 in that appellants were not 
If, during the hearing, respondent believes he will be prejudiced or jeopardized by reason of inability to fully present his case, the hearing officer will be found receptive to such postponements or continuances as may be necessary to afford the full right of each such respondent to make a complete presentation of his case. This receptivity should not be abused. A frank statement should be made about the nature of the information for which the continuance is desired, why it was not available in sufficient time, and what effort was made to have it available at the time scheduled for the hearing. ${ }^{64}$

The scope of hearings under this act is broad enough to include evidence which may not be specifically relevant to the issues involved, but may tend to show mitigation either of the offense charged or the sanction that may be imposed. In criminal cases this matter would be deferred to a probation officer's report, but here should be presented at the hearing. Where a hearing officer sits alone, the act requires him to prepare a proposed decision including a proposed "penalty." part by such facts as would have a reasonable bearing upon the determination of the severity or degree of the offense or the penalty which might otherwise be appropriate.

Disciplinary hearings under the act relate to a valuable right of the client, and counsel should not attempt to excuse a careless or informal (fireside justice) presentation by an assertion that the proceedings are informal. Such excuse does not relieve counsel from an obligation of thorough, careful preparation on all legal questions that may arise as well as sound preparation and presentation of relevant evidence, including exhibits.

Upon closing and submitting the matter one should check to see that all identified exhibits have been offered in evidence. Counsel should also request that any rulings which may have been deferred now be made on the record. Ordinarily, a closing argument contributes little, since careful attention, generally, has been given to the proceeding. But a brief summary or marshaling of the evidence may not be inappropriate. Inquiry should be

informed that the "Department had included in appellants' record a notation of a conviction for a violation of the Health and Safety Code and that it would be used against them in the present proceeding. Appellants were informed of this particular item of 'official notice' through the service of the decision upon them. They immediately filed a petition for rehearing with the Department of Alcoholic Beverage Control and called the Department's attention to the fact that the record of conviction was of previous owners of the New Yorker. This petition was denied without a correction of the record, leaving appellants with this prejudicial finding against thein. Such procedure was in violation of the law. Fair play requires that appellants receive notice of any evidence that is to be received against them." The Board reversed the Department.

64 See text at note 54, and note 54 supra, which deal with opportunities for postponements or continuances if an anended accusation is filed (CAL. GovT. CoDE $\$ 11516$ ).

65 Cal. Govt. Code $\$ 11518$. 
made of the presiding officer whether such argument is desired. In the event any controverted legal points have been raised, one might offer to file briefs or a memorandum of points and authorities bearing on such points.

Upon submission one might inquire whether the agency intends to announce its decision at the close of the executive session. Particularly where the matter has been heard by a hearing officer sitting alone, no decision may be immediately forthcoming. The matter will be taken under submission. The hearing officer will prepare a proposed decision in the appropriate form ${ }^{66}$ and forward it to the agency. This proposed decision or a copy thereof "shall be filed by the agency as a public record and a copy served by the agency on each party and his attorney." ${ }^{\prime 67}$ If the agency itself heard the case, its decision will be so served.

If it is a proposed decision, the agency may adopt the proposed decision as submitted or may reduce the proposed penalty or sanction and adopt the balance of the proposed decision. ${ }^{68}$ In the event neither of these alternatives is acceptable to it, the agency may announce its nonadoption and that it will "decide the case upon the record, including the transcript, with or without taking additional evidence, or [it] may refer the case to the same or another hearing officer to take additional evidence." In such event, the agency is also required to afford "the parties the opportumity to present either oral or written arguments before the agency itself."

Upon such referral or reopening, and as ordered by the agency, the proceeding before a hearing officer will follow the normal sequence. If the agency orders the taking of further evidence at the time it hears oral argument, the act says that "no agency member may vote unless he heard the additional oral evidence." 70

66 Ibid. Considerable flexibility is possible in the form of order. Some agencies have wide latitude, e.g., Car. BuS. \& Pror. CODE $\$ 2372$ (inedical board); id. $\$ 7095$ (contractors); id. $\S 10156.5$ (real estate); and see CAI. INs. CODE $\$ 1690$.

67 CaI. Govt. CoDE $\$ 11517$ (b). The section generally relates to the decision and what happens to it. The act prescribes the form of decision. The officers of the Division of Administrative Procedure usually prepare the decision for the agency based upon its findings of fact, determination of issues and the penalty, and do so in the form required by Government Code section 11518. When the hearing officer sits alone he is to prepare his proposed decision in that required form. Draftsmanship of the decision can be salutary. Dare v. Board of Medical Exammers, 21 Cal.2d 790, 136 P.2d 304 (1943), indicates that a reviewing court, even when referred to as a "trial" court, and in those instances where such court indulges in a limited or qualified trial de novo, i.e. "exercises its independent judgment on the evidence," examines the record carefully. See CaL. Cone CIv. Proc. $\$ 1094.5$ (c). When the decision is well drawn and clearly indicates what the agency has done on the record, it leaves less room for the court to remand or reverse.

68 Cax. Govr. Code $\$ 11517$.

$601 d . \S 11517(\mathrm{c})$.

70 Similar language appears in subdivision (a) of $i d$. $\$ 11517$. The supreme court said in Cooper v. State Bd. of Medical Examiners, 35 Cal.2d 243, 217 P.2d 630 (1950), that reading the transcript is hearing the testimony. Quaere: Is this true under subdivision (c) as well as (a) ? And see Moyer v. State Board of Equalization, 140 A.C.A. 715, 295 P.2d 583 (1956). 
Posthearing procedures will now occupy the attention of counsel. Reference has already been made to an amendment after submission, and to procedures relating to the nonadoption of a proposed decision. ${ }^{71}$ Official notice may be taken of an appropriate matter after submission of the case. ${ }^{72}$ In these instances opportunities will be presented to the affected parties to fully present relevant matters in order that the record may be full and complete and free from prejudice.

The order or decision will be served upon or delivered by registered (or certified) mail to respondent. It will disclose an effective date of the decision. ${ }^{73}$ Counsel should not rely on the thirty days mentioned in the section, but should examine the order carefully as the agency may have accelerated the effective date. ${ }^{74}$ This is a most significant date as it terminates the time within which an agency may order a reconsideration of the case after its order has been made. ${ }^{75}$ Its power to reconsider expires on the effective date whether it be the thirtieth day after the delivery or mailing by operation of law, or on an earlier date in the event the agency has accelerated that date. If reconsideration has been granted the nature and extent thereof will be disclosed by the order or established at the hearing thereon in accordance with the record and appropriate subsequent orders of the agency. $^{76}$

A recent amendment to the section on reconsideration may have added flexibility or confusion. It is now provided that the agency power to order reconsideration expires on the effective date "or at the termination of a stay of not to exceed 30 days which the agency may grant for the purpose of filing an application for reconsideration." "Th This power is limited in time and purpose. A petition invoking this power should be as complete a statement as possible of the grounds on which reconsideration is requested. The proceeding appears to be similar to a petition for a new trial in court. The interest in speedy determinations may induce a refusal to grant reconsideration on a bare request for it. The request should be filed early so that the agency can act upon it while power to do so exists. If it is granted, the agency will then or later direct the scope, manner, time, and place to make the showing or argument on which the agency may act. If reconsideration is granted, the previous order is vacated and the decision will not become effective.

71 See text at notes 54 and 68 supre.

72 CAT. Govt. CoDE $\$ 11515$.

73 Id. $\$ 11519$.

74 Hohreiter v. Garrison, 81 Cal. App.2d 384, 184 P.2d 323 (1947).

75 CAL. Govt. CODE § 11521 (a).

${ }^{76} I d . \$ 11521$ (b). A word of caution: Make every effort to act promptly within the time schedule as the agency's power to act is limited. It probably bas no nunc pro tunc authority. See Kuchoman, Catifornta Administrative Law 66 (1953).

77 CAI. Govt. Code \$11521(a). 
Ultimately a definitive order will be available and the administrative remedies are then exhausted. The act states that "the right to petition [for judicial review] shall not be affected by the failure to seek reconsideration before the agency." 778

Judicial review, the next step in counsel's activities in representation of his client, is a subject developed at considerable length in a preceding article in this symposium.

78 Id. \& 11523. 